\title{
Peertechz
}

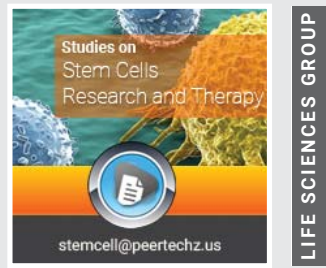

\section{Stem Cell - De Novo Treatment Disorders}

\section{AD Diwan* and SN Harke}

Mahatma Gandhi Mission's University (MGM), Institute of Biosciences and Technology, N-6, CIDCO

Aurangabad-431003 Maharashtra State, India
Received: 07 June, 2021

Accepted: 16 June, 2021

Published: 17 June, 2021

*Corresponding author: AD Diwan, Mahatma Gandhi Mission's University (MGM), Institute of Biosciences and Technology, N-6, CIDCO, Aurangabad-431003 Maharashtra State, India, E-mail: arvinddiwan@yahoo.com https://www.peertechzpublications.com

\section{Check for updates}

\section{Introduction}

In recent past, several research papers mentioned that stem cells can cure ailments of even serious nature whether acute or chronic in humans and also in other animals. Basic and clinical research accomplished during the last few years on embryonic, fetal, amniotic, umbilical cord blood, and adult stem cells has constituted a revolution in regenerative medicine and cancer therapies by providing the possibility of generating multiple therapeutically useful cell types. These new cells could be used for treating numerous genetic and degenerative disorders. Among them, age-related functional defects, hematopoietic and immune system disorders, heart failures, chronic liver injuries, diabetes, Parkinson's and Alzheimer's diseases, arthritis, and muscular, skin, lung, eye, and digestive disorders as well as aggressive and recurrent cancers could be successfully treated by stem cell-based therapies [1-5].

A South Korean woman paralysed for 20 years has recouped walking after Scientist's repaired her damaged spine using stem cells derived from Umbilical Cord blood. This might be the world's first published report in which a patient with spinal cord injuries had been successfully treated with stem cells from Umbilical Cord blood [6].For the therapy, multipotent stem cells were isolated from Umbilical Cord blood, which had been frozen immediately after the birth of a baby and cultured for a period of time. Then, these cells were directly injected to the damaged part of the spinal cord. Earlier, bone marrow cells have been used to treat cancer patients with conditions such as leukemia and lymphoma.During chemotherapy, most growing cells are killed by the cyto-toxic agents. These agents not only kill the leukemia or neoplastic cells, but also the stem cells needed to replace the killed cells as patient recovers. However, if the stem cells are removed before chemotherapy, and then re-injected after treatment is terminated, the stem cells in the bone marrow produce large amounts of red and white blood cells, to keep the body healthy and to help fight infections. In recent past, stem cells have been taken from the blood instead of bone marrow, making the procedure safer for older people. Normally less number of peripheral blood cells can be increased by a course of drugs, which release the stem cells from the bone marrow. These are removed before chemotherapy, which kills most of them and re-injected afterwards [7]. The group of scientists who achieved worldwide fame for cloning the sheep 'dolly' have successfully created heart tissue using cow stem cells. It was demonstrated that the stem cells could be transformed into differentiated bodily tissues, offering great scope for further research [8]. It has been reported that Scientists at Enzi Biochem Inc made an attempt through stem cell therapy using bone marrow transplantation technique to treat HIV infections and other types of cancers. The exciting HIV experiments were conducted using stem cells found in patient's own bone marrow, spleen or blood [9]. Chinese scientists working in US have claimed success in coaxing human embryonic stem cells to become spinal motor neurons, which could help treat diseased critical nervous system. Motor neurons transmit messages from the brain, dictating almost every body movements [10]. It is surprising to note that these remarkable achievements relied on the use of stem cells from embryos or the products of abortion, however, all these involved use of adult stem cells or from non-embryo resources. But the breathless stories extolling the miraculous potential of embryonic stem cell research is now gaining immense importance. In several countries, many research laboratories and hospitals are engaged in stem cell research. Advanced development in this particular area of science has given confidence to researchers and doctors to take up clinical applications in damaged organ treatment. The concept is that using several thousands of stem cells that are capable of transforming themselves into almost any kind of tissue from suffering patients and injecting them into the heart for its repair. Many institutions in India and other countries have successfully treated such chronic ailments using stem 
cells. Therefore, stem cell research and its application will help in providing cost effective treatment of many incurable and deadly diseases. However, controversy still exists for use of human stem cells from embryos, as these cells are derived from couples who use in-vitro fertilization. A survey by the Society for Assisted Reproductive Technology reported that nearly 4.00 lakh such embryos are stored in cryopreservation facilities in USA, of which 11,200 are available for research. Because harvesting such cells destroys the embryo, which means destruction of human life [11]. The latest research published in the Journal of Clinical Investigation has reported that monkey stem cells can be used to repair brain damage caused by the Parkinson's disease. When stem cells are grown in to brain cells or neurons damaged in Parkinson's disease, they seem to protect the dopamine producing neurons. Scientists transplanted the stem cell derived dopamine producing neurons into monkeys with condition analogous to human Parkinson's disease. The transplanted cells worked as hoped, reducing the symptoms of Parkinson's disease in affected monkeys [12].

Parkinson's disease is caused when key brain cells that produce - message -carrying chemical dopamine die off. Symptoms start with patient trembling and he/she can end up paralyzed there is no cure for Parkinson's disease. The application of stem cell research is not only restricted to human health science but also in other areas like animal sciences including fisheries and aquaculture. It is a known fact that worldwide there is a decline in number of wild species of fish and shellfish which calls for strategies to restore endangered population. And answer to this is use of stem cells from embryos of such animals for their mass scale production. In one of the reports, published in Nature [13] describes successful production of salmon using stem cells of rainbow trout embryos. As cryopreservation of egg and embryos has so far been unsuccessful for fish, Primordial Germ Cell (PGC) xenotransplantation in combination with PGC cryopreservation could be a useful strategy for helping the conservation of endangered species of fish.

\section{What are stem cells}

Stem cells are primal undifferentiated 'master cells' in the body which have the potential to produce any kind of cell in the body. Stem cell research may lead to exponential improvements in the treatment of many terminal and debilitating conditions, from cancer to Parkinson's to Alzheimer's to diabetes to heart disease. Medical researches believed that stem cells have the potential to change the face of human diseases by being used to repair specific tissues or to grow organs [14].

\section{Types of stem cells}

There are three types of stem cells viz. totipotent, pluripotent, and multipotent. A single totipotent stem cell can grow into an entire organism. Pluripotent stem cells can not grow into a whole organ, but they can become any other type of cell in the body. Multi-potent stem cells can only become particular types of cells e.g. blood cells, or bone cells [14].
Stem cells are also categorized according to their source, as either adults or embryonic. Adult stem cells are already being used in treatments for over 100 diseases and conditions, while embryonic stem cell research is a less developed field and is considered by many researchers to have greater potential as the basis of treatments. Research with embryonic stem cell is controversial also because it requires destruction of embryos, which too many people are human beings, meaning that destroying an embryo for any reason is morally unacceptable. On the other side of the issue, people point out that embryonic stem cells have a potential to cure most diseases, and the embryos used would have been discarded by fertility clinics [14].

\section{Sources of stem cells}

Cord blood stem cells: Blood from the placenta and umbilical cord that are left over after birth is a source of adult stem cells. It is collected by removing the umbilical cord, cleansing it and withdrawing blood from the umbilical vein. This blood is then immediately analysed for infectious agents and the tissue type is determined. Cord blood is stored in liquid nitrogen for later use [15].

Adult Stem Cells: Stem cells can be found in adult beings. Adult stem cells reproduce daily to provide certain specialized cells - e.g. 200 billion red blood cells are created each day in the body. Until recently, it was thought that each of these cells could produce just one type of particular cells -which is called differentiation. However, in the past few years, evidence has been gathered of stem cells that can transform into several different forms. Bone marrow stem cells are known to be able to transform into liver, nerve, muscle and kidney cells [14] (Figure 1).

Adult stem cells may be even more versatile than this. Researchers at the New York University, School of Medicine have extracted stem cells from the bone marrow of mice which they say are pluripotent. Turning one type of stem cell into another is called transdifferentiation.

In fact, useful sources of adult stem cells are being found in organs all over the body. Researchers at the McGill University in Montreal have extracted stem cells from skin that are able to differentiate into many types of tissues, including neurons, smooth muscle cells and fat-cells. These were found in

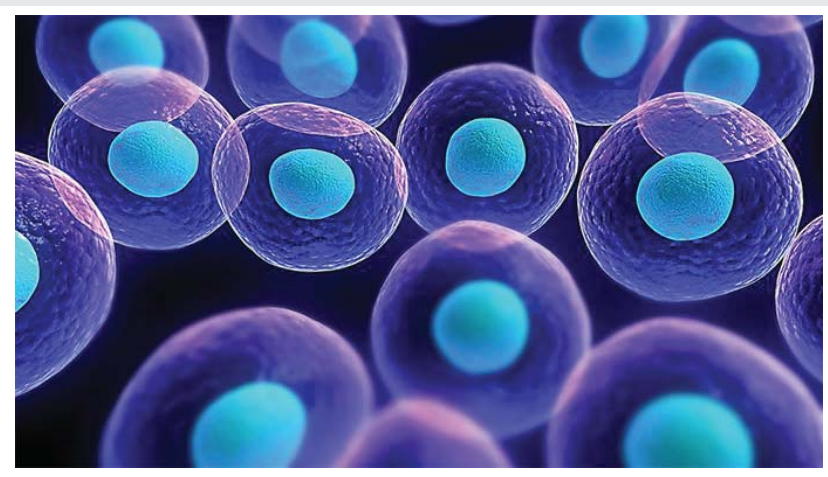

Figure 1: Adult stem cell (source: internet web). 
"dermis" the inner layer of the skin. These stem cells play a pivotal role in healing small cuts. Adult stem cells have already successfully treated over one hundred diseases and conditions, while embryonic stem cell research has not yet generated any treatments [16].

There are, however, at least presently, limitations to using adult stem cells although many different kinds of multi-potent stem cells have been identified, adult stem cells yet could give rise to all cell and tissue types have not yet been found. Adult stem cells are often present in only minute quantities and can therefore been difficult to isolate and purify. There is also evidence that they may not have the same capacity to multiply as embryonic stem cells do. Finally, adult stem cells may contain more DNA abnormalities caused by sunlight, toxins, and errors in making more DNA copies during the course of a life time. These potential weaknesses might limit the usefulness of adult stem cells in comparison with embryonic stem cells [17].

\section{Embryonic stem cells}

Stem cells which originate from embryos are seemed to have the most potential because of their totipotent properties - they are able to grow into any of the two hundred cell types in the body. Embryonic stem cells can be obtained from a cloned embryo, created by fusing a denucleated egg cell with a patient's cell. The embryo produce is allowed to grow to the size of a few tens of cells, and stem cells are then extracted. Because they are obtained from a clone, they are genetically compatible with the patient (Figure 2).

\section{Potential uses of stem cells}

Theoretically, virtually, any disease could in time be treated by stem cells. Research injecting neural adult stem cells into the brains of rats can be astonishingly successful in treating cancerous tumors. With traditional techniques, brain cancer is almost impossible to treat because it spreads so rapidly. Researchers at the Harvard Medical School injected cells genetically engineered to convert a separately injected nontoxic substance into a cancer killing agent. Within days the cells had migrated into the cancerous area and the injected substance was able to reduce tumor mass by 80 per cent.

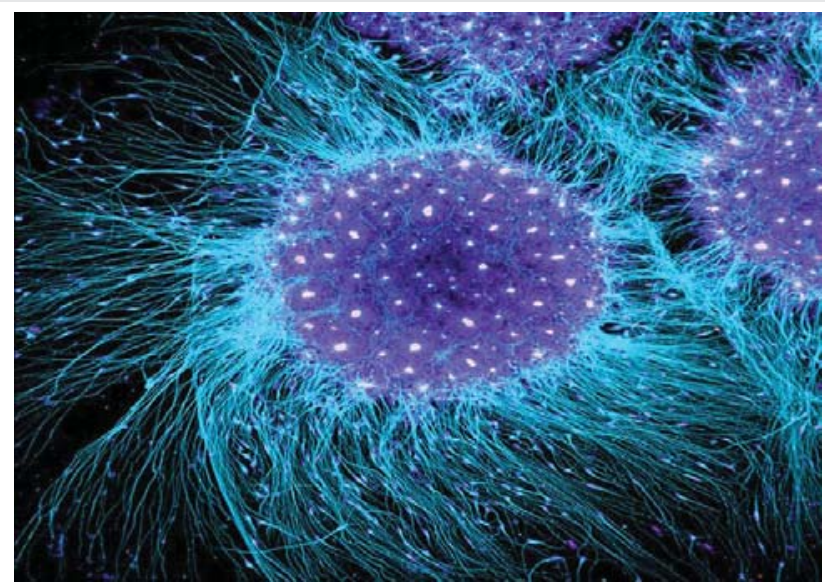

Figure 2: Human embryonic stem cells, assemble into spheres in culture.

Credit: Gist Croft / Ali Brivanlou / Rockefeller University.
Stem cells are also apparently be able to repair mussel damage after heart attacks. Researchers at Columbia Presbyterian found that injecting bone marrow stem cells into mice which had heart attacks induced resulted in an improvement of $33 \%$ in the functioning of the heart. The damaged tissue had re-grown by $68 \%[18,19]$.

Working with critically ill heart patients, researchers in Vienna have successfully used Mesenchymal stem cells to regenerate healthy new heart tissue. The stem cells were harvested from the patients own bone marrow and injected into the ventricle. The heart is stopped for approximately two minutes to allow the stem cells to attach to the existing heart tissue. All the patients that received the new treatment experienced repaired scar tissue and most had nearly complete return of proper heart function. Normally, stem cells have to be transplanted from the bone marrow or from embryos. But new research by Sara Rankin of Imperial College of London has provided a major breakthrough-drug that boosts release of stem cells. Stem cells from the bone marrow can turn into new blood vessels and make tissues, such as bone and cartilage, and would therefore be useful for treating patients with broken bones or heart disease. At Harvard Medical School Doug Melton has developed insulin producing cells from skin cells by using stem cells. This is a major step forward towards treating diabetes. What remains to be done is to prevent the autoimmune attack on these new cells [20].

Takeuchi and his associates from Tokyo University of Marine Science \& Technology, Japan have mentioned that the primordial germ cell of one species of fish can be successfully transplanted into another species of fish, producing the offspring having phytogenic characters. By applying this particular technique of using embryonic stem cells of salmon, one could be able to multiply the population of salmon and conserve such endangered species of fish. This opens the possibility of use of stem cell in the field of fisheries not only to recoup declining of fishery but also to produce new traits of desired quality [13].

\section{Stem Cell research - controversy in the usage of knowle- dge}

The controversy surrounding stem cell research led to an intense debate about ethics. Up until the recent years, the research method mainly focused on Embryonic Stem Cells, which involves taking tissue from an aborted embryo to get proper material to study. This is typically done just days after conception or between the 5 th and 9 th week.

Since then, researchers have moved on to more ethical study methods, such as Induced Pluripotent Stem Cells (iPS). iPS are artificially derived from a non-pluripotent cell, such as adult somatic cells.

This is probably an important advancement in stem cell research, since it allows researchers to obtain pluripotent stem cells, which are important in research, without the controversial use of embryos. 
There were two main issues concerning stem cell research with both pros and cons:

1. How the knowledge will be used

2. Concerns about the methods.

The first issue is really not just about stem cell research, as it may be applied to most research about human health.

Since 2007, the second point, concerns about the methods involved.

Stem cell research can potentially help treating a range of medical problems. It could lead humanity closer to better treat and possibly cure a number of diseases (Figure 3):

- Parkinson's Disease

- Alzheimer's Disease

- Heart Diseases, Stroke and Diabetes (Type 1)

- Birth Defects

- Spinal Cord Injuries

- Replace or Repair Damaged Organs

- Reduced Risk of Transplantation (You could possibly get a copy of your own heart in a heart-transplantation in the future

- Stem cells may play a major role in cancer

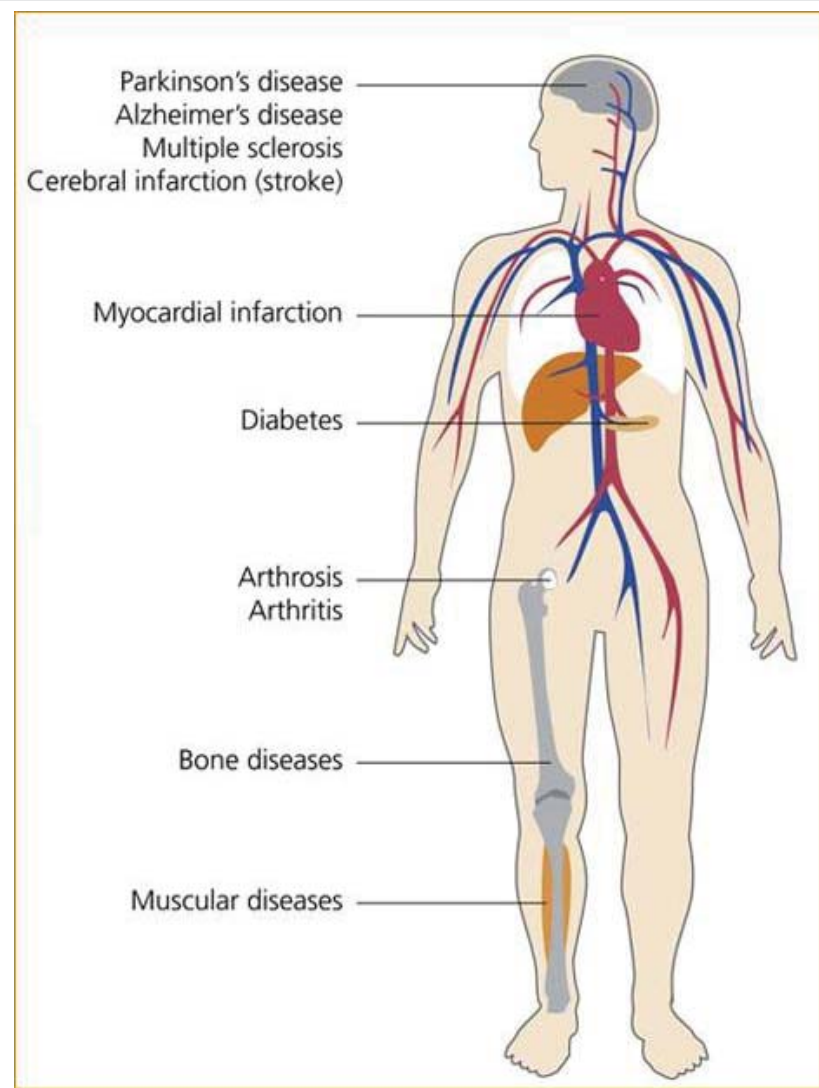

Figure 3: Stem cell applications in treatment of various disease disorders (source: internet web)
Better treatment of these diseases could also give significant social benefits for individuals and economic gains for society.

\section{Government of India's policy to regulate use of stem cell}

Government of India has drawn up a plan to effectively review and monitor the way stem cell research being conducted in the country. An effective surveillance on the highly complex stem cell research is yet to be in practice in India even though the country has already worked out the fundamental guidelines for stem cell research in 2017 [21].

Indian Council of Medical Research (ICMR) - the apex body regulating medical research in India -and the Department of Biotechnology (DBT) under the Ministry of Science and Technology, Government of India announced the guidelines for stem cell research and therapy way back in 2007. The Guidelines for Stem Cell Research and Therapy in 2007 which were later revised after public consultations and released as National Guidelines for Stem Cell Research (NGSCR-2013). The National Guidelines for Stem Cell Research, 2017 is an outcome of concerted efforts of different stakeholders. It has been formulated taking into account several new scientific and technical advancements as well as the perceived challenges in the field. Efforts were made to bring together all concerned ministries/agencies to chalk out strategies to curb rampant unethical practices of banking and therapeutic application. The recommendations of the Inter-Ministerial/Inter-Agency meetings have helped to shape these guidelines. Detailed and extensive consultation with stakeholders were held and their suggestions taken into account before finalization. Most importantly, the guidelines have been harmonized with existing rules and regulations.

National Apex Committee (NAC) under the health ministry for Stem Cell Research has been constituted to look after the procedures to be adopted for use of stem cells by research institutions in the country. NAC, comprised of experts from various fields, is responsible for examining the scientific, technical, ethical, legal and social issues in the area of stem cell based research and therapy. Legal expert, social scientist, and a women's representative are also be part of NAC. The NAC could also consult outside experts on a case to case basis. Institutions involved in stem cell research and therapy will have to be registered with the NAC through Institutional Committee for Stem Cell Research and Therapy (IC-SCRT). NAC will set standards for procedures for collection, processing, differentiation, preservation and storage of human tissues to their assure quality and sterility.

The National Guidelines for Stem Cell Research (NGSCR)-2017 takes into consideration many issues related to the use of stem cell research and also its therapeutical aspects. The guiding philosophy of these guidelines is prevention of premature commercialization of unproven stem cell therapies and generation of new knowledge based on sound scientific rationale while addressing all ethical concerns. These guidelines are applicable to all stakeholders including individual researchers, organizations, sponsors, regulatory committees 
and all others associated with both basic and clinical research involving any kind of human stem cells and their derivatives. The guidelines do not apply to research using non-human stem cells and their derivatives. Further, these do not apply to use of hematopoietic stem cells for treatment of various hematological, immunological and metabolic disorders since these have already been established as a standard of medical care. The guidelines reiterate that the general principles of ethics for biomedical research involving human participants shall also be applicable. In addition, the guidelines specify unique provisions for stem cells, because of their inherent property for unlimited proliferation, differentiation to cells of the germ layers, oncogenic potential, unrecognized toxicities and possible involvement in pre-implantation stages of human development. The guidelines have been laid down to ensure that all research with human stem cells is conducted in an ethical and scientifically responsible manner. All stakeholders are required to comply with all regulatory requirements pertaining to biomedical research in general and stem cell research in particular.

There are over three dozen research institutes, hospitals, and firms involved in stem cell research in India. These sites include large public hospitals such as the All India Institute of Medical Sciences (AIIMS) and private firms such as Life Cell in Chennai, and research institutes such as the National Centre for Cell Sciences (NCCS) in Pune. Jawaharlal Nehru Centre for Advanced Scientific Research (JNCASR), Bangalore studies the fundamental issues in stem cell applications into cardiovascular cells. NCCS has conducted animal and preclinical analyses of bone marrow stem cell injections for pancreatic regeneration. Christian Medical College and Hospital (CMC) in Vellore has a centre for stem cell research in collaboration with DBT Sankara Nethralaya also has a facility for stem cell research which focuses on corneal stem cells, cancer stem cells, and the use of stem cells in tissue engineering. Stempeutics Research, a biotechnology company developing stem cell based medicinal products, is reportedly in the process launch its investigational new drug for acute myocardial infarction and critical limb ischemia in India by 2012. Stempeutics' is considered the first DCGI and ICMR approved clinical trial using adult allogenic mesenchymal stem cells from the bone marrow. Most stem cell research companies in India depend on umbilical cord blood banking as their primary source. Life Cell of Chennai, Cryo Stem Cell of Bangalore, and Reliance Life Sciences of Mumbai have umbilical cord blood banking facilities. Reliance Life Sciences is also learnt to be engaged in developing cell-based therapies to address neural, cardiac and metabolic disorders.

Over the past few years, India has seen a surge in the stem cell business. Apart from several foreign companies, the industry has witnessed the mushrooming of small domestic firms. According to industry estimates, the domestic market size is more Rs.100 crores now and growing at an annual pace of $40 \%$. However, the size of the Asia Pacific Stem Cell Market is forecasted to grow US\$ 5330 million by end of 2025 . The stem cell market is expected to grow at a formidable rate during coming few years. Continuous advancements in tissue engineering is one of the prime factors responsible for the growth of India stem cell market. Development of regenerative medicines coupled with growing cases of chronic and genetic diseases across the country are some of the other factors anticipated to drive the growth of stem cell market during the forecast years. Moreover, availability of funds from the government and certain organizations is estimated to bode well for the growth of India stem cell market during the next 5 years.

\section{Conclusion}

The stem cell-research is an example of the, sometimes difficult, cost-benefit analysis in ethics which scientists needs to do. Even though many issues regarding the ethics of stem cell research have now been solved, it serves as a valuable example of ethical cost-benefit analysis. When we are planning a research project, ethics must always be considered. If we cannot defend a study ethically, we should not do it. The analysis needs to include human/animal discomfort/risks environmental issues, material costs/benefits, economy etc.

\section{Acknowledgement}

Authors would like to express their sincere thanks to Shri Ankushrao Kadam, Secretary and Chancellor, MGM University, Aurangabad, Maharashtra, India for his constant support and encouragement to undertake such challenging reviews

\section{References}

1. Mahla RS (2016) Stem cells application in regenerative medicine and disease therapeutics. Int J Cell Biol 1-24. Link: https://bit.ly/3gBU8KJ

2. Müller AM, Huppertz S, Henschler R (2016) Hematopoietic Stem Cells in Regenerative Medicine: Astray or on the Path?. Transfus Med Hemother 43 247-254. Link: https://bit.ly/2S711vo

3. Lyon L (2018) Stem cell therapies in neurology: The good, the bad and the unknown. Brain 141: e77. Link: https://bit.ly/3xtfUHu

4. Biehl Jesse K, Russell B (2009) Introduction to Stem Cell Therapy. J Cardiovasc Nurs 24: 98-105. Link: https://bit.ly/3gtaV3M

5. Wojciech Z, Dobrzyński M, Szymonowicz M, Rybak Z (2019) "Stem Cells: Past, Present and Future. Stem Cell Res Ther 10: 18. Link: https://bit.ly/35r7zYz

6. Mathew C (2006) Motherhood- Biotechnological research and its religioethical implications. Asvattha: International Journal of Culture, Philosophy and Theology 12: 1-10.

7. Baylis F, Robert JS (2006) Human Embryonic Stem Cell Research: An Argument for National Research Review. Account Res 13. 207-224. Link: https://bit.ly/3iNQSie

8. Fridovich K, Judith L (2020) "Dolly". Encyclopedia Britannica. Link: https://bit.ly/3gv0X1K

9. Allers K, Hütter G, Hofmann J, Loddenkemper C, Rieger K, et al. (2014) Evidence for the cure of HIV infection by CCR $5 \Delta 32 / \Delta 32$ stem cell transplantation. Blood 117: 2791-299. Link: https://bit.ly/3gCedk9

10. Chinese scientists grow embryonic stem cells to motor neurons (2004) Published news.

11. Elizabeth W (2003) USA's Stem Cell Scientists Fear a Research Brain Drain. Por Bill Freeman.

12. Parkinson's damage repaired (2005) News Services, BBC News, $3^{\text {rd }}$ January, News.bbc.co.uk. 
13. Yutaka T, Goro Y, Toshio T (2004) Surrogate brood stock produces salmonids Nature 430: 629-630. Link: https://go.nature.com/3xssITP

14. Atala A, Lanza R (2012) Handbook of Stem Cells. Academic Press 452.

15. Kirsten R (2009) Cord blood stem cell. Stem Cell Research. The Centre For Bioethics \& Humanity Dignity 16

16. Greg M (2001) Adult stem cells found in Skin. Nature Cell Biology 3: 778. Link: https://bit.ly/3gvXQqo

17. Paula SR (2013) Vatican gets behind adult stem cell research. Reporter. Official News paper of the Lutheran Church, Missouri Synod. Link: https://bit.ly/3pZVUtv
18. Kruse C, Danner S, Rapoport D (2008) Current Stem Cell Technology: Limitations and Realistic Expectations. Link: https://bit.ly/3gCJCTn

19. Tanne J (2005) US stem cell research progresses despite limitations. BM 330: 1467. Link: https://bit.ly/3zAP3uH

20. Felicia WP, Jeffrey RM, Mads G, Michael S, Alana VD, et al. (2014) Generation of Functional Human Pancreatic b Cells In Vitro. Cell 159: 428-439. Link: https://bit.ly/3iNTHQm

21. National Guidelines for Stem Cell Research (2017) Published by the Division of Publication and Information on behalf of the Secretary DHR \& DG, ICMR, New Delhi.
Discover a bigger Impact and Visibility of your article publication with

Peertechz Publications

\section{Highlights}

* Signatory publisher of ORCID

* Signatory Publisher of DORA (San Francisco Declaration on Research Assessment)

* Articles archived in worlds' renowned service providers such as Portico, CNKI, AGRIS, TDNet, Base (Bielefeld University Library), CrossRef, Scilit, J-Gate etc.

* Journals indexed in ICMJE, SHERPA/ROMEO, Google Scholar etc.

- OAI-PMH (Open Archives Initiative Protocol for Metadata Harvesting)

* Dedicated Editorial Board for every journal

* Accurate and rapid peer-review process

- Increased citations of published articles through promotions

* Reduced timeline for article publication

Submit your articles and experience a new surge in publication services (https://www.peertechz.com/submission).

Peertechz journals wishes everlasting success in your every endeavours.

Copyright: @ 2021 Diwan A, et al. This is an open-access article distributed under the terms of the Creative Commons Attribution License, which permits unrestricted use distribution, and reproduction in any medium, provided the original author and source are credited. 